\title{
Judá na passagem do século VIII ao VII: os reinados de Ezequias e Amon
}

\author{
Orientadora: Prof $f^{a}$. Maria de Lourdes Corrêa Lima \\ Pesquisador: José Diógenes Dias Gonçalves \\ Fonte: $\mathrm{CNPq}$ \\ Introdução
}

O final do século VIII até meados do século VII a.C., em Judá, constitui um dos períodos mais relevantes da monarquia do reino do Sul, na medida em que entram em cena reis com visões fundamentalmente opostas acerca da submissão à Assíria, de um lado, e da prática religiosa javista, de outro. A época de Ezequias foi marcada por revoltas de Judá contra o poder assírio, segundo uma política de coalizões; de outro lado, a ele é atribuída uma reforma religiosa significativa, em direção a um javismo mais purificado do que aquele vivido na época de seus antecessores. Durante seu reinado é também colocada uma relevante atividade literária (cf. Pr 25,1). Seus sucessores (Manassés e Amon) adotaram uma política de submissão à Assíria, que acarretou consequências não só políticas mas também no plano religioso.

O presente projeto visou, nesse sentido, a: apresentar os dados mais relevantes dos estudos de cunho histórico e arqueológico sobre os reinados de Ezequias, Manassés e Amon, comparando-os com os dados bíblicos e integrando-os com a pesquisa mais recente sobre a compreensão da história neles presente. A relevância desta pesquisa demonstra-se pelo fato de pôr à luz a história do antigo Israel e de compreender mais adequadamente o texto bíblico e sua peculiar interpretação dos fatos.

Referencial no trabalho foram as pesquisas recentes da arqueologia no território de Israel e da historiografia (Finkelstein; Liverani; Mazar).

\section{Objetivos}

Apresentar os dados trazidos pela arqueologia e historiografia mais recentes, traçando o cenário internacional no final do século VIII até meados do século VII, abordando os aspectos da religião e do culto no Reino de Judá anterior a Ezequias e na época de Manassés e Amon; por fim, refletir sobre a perspectiva dos textos bíblicos que relatam os acontecimentos deste período. 